Lebedev, S.V. (2020). Opportunities for the development of Russian folk art in the 21 st century. Current issues of cultural heritage in 2020. Collection of Scientific Articles, 1 (1), 5-23. European Scientific e-Journal. Hlučín-Bobrovníky: “Anisiia Tomanek” OSVČ.

DOI: $10.47451 / \operatorname{art} 2020-08-003$

EOI: $10.11244 / \operatorname{art} 2020-08-003$

The paper is published in Crossref, Internet Archive, Google Scholar, Academic Resource Index ResearchBib, JGate, ISI, CiteFactor, ICI, eLibrary databases.

Sergey V. Lebedev

Full Professor, Doctor of Philosophical Sciences

Head of the Department of philosophy

Higher School of Folk Arts (Academy)

St Petersburg, Russia.

E-mail: servicleb@list.ru

\title{
Opportunities for the development of Russian folk art in the 21st century
}

\section{Abstract:}

Folk art, including Russian folk art, existed and developed throughout the 20th century and continues to exist in the 21st century. Russian traditional art is well-known in the world. When in any country of the world, a local resident is asked what the word 'Russia' is associated with, then usually in response along with frosts, bears, vodka, Troika, samovar, balalaika and the Kalashnikov, it is also called such concepts as 'Palekh', 'Gzhel', and 'Khokhloma'. The reason for this is the peculiarity of the existence of folk art, based on the traditions of the ethnic group. The author concludes that Russian traditional applied art having survived all the troubles and misfortunes, continues to exist. At the same time, traditional art directly affects the 'high' art of the nation.

Keyword:

Folk art, tradition, folk, traditional art, handicrafts, art industry.

\section{Introduction}

Russian traditional art is well-known in the world. When in any country of the world, a local resident is asked what the word 'Russia' is associated with, then usually in response along with frosts, bears, vodka, Troika, samovar, balalaika and the Kalashnikov, it is also called such concepts as 'Palekh', 'Gzhel', and 'Khokhloma'.

However, maybe is all this a legacy of the last century? In most European countries, folk art disappeared in the 19th century, and was finally 'finished off' in the 20th century. Only kitsch producing crafts for tourists, remained. However, for example, when a tourist buys keychain in the form of the Eiffel tower made in China 
from an Afro-French merchant in Paris, it cannot be considered an indicator of the existence of folk art in France.

However, unlike most industrialized countries, traditional folk art still exists in Russia today. Moreover, Russian folk art, which developed in immemorial times (for example, the art of wood or bone carving was formed in the Neolithic era), was developing during the industrial epoch of Russia. For example, some of famous Russian art crafts originated in the Soviet period of the history:

- Russian lacquer miniatures (Palekh, Mstera, Kholui) were formed in the 1920s and 1930s;

- Cossack filigree appeared in the 1930s and 1940s;

- the art of artistic processing of amber, popular among the Baltic peoples, but not widely spread among Russians, was born in the Kaliningrad region after 1945;

- Varnava bone carving appeared in the late 1960s.

Some Russian arts and crafts experienced periods of decline and a new Renaissance. So, in Soviet times, nearly extinct Rostov enamel, painted Zhostovo metal trays, Kholmogory bone carving, Veliky Ustyug blackening on silver and Zlatoust steel engraving was revived. In the 1970s, the art of Nizhny Tagil metal painting was revived, too.

However, back to the questions:

Is it possible for folk art to exist in Russia in the 21 st century?

Whether it would be consigned to history?

As the philosopher Descartes said, "define words correctly, and you will free the world from half of its errors." Let's start with the term of 'tradition' and find out whether it is fair to call folk art by traditional one.

Tradition (lat. traditio is 'transmission', 'delivery') - historically formed and transmitted from generation to generation, customs, rituals, social institutions, ideas and values, norms of behavior, etc., elements of social and cultural heritage, preserved in society. The very concept of 'tradition' means the continuity of knowledge and research methods, but in art it means the continuity of style and skill. In a broad sense, tradition is an expression of all that is previous and stable in the life of society, and it accumulates all the previous experience of collective activity.

Traditions are a necessary condition for the life of a nation. They also have an integrative character for ethnic communities for 'own' and separate from 'others'. In pre-capitalist societies, traditions regulated all spheres of life of the individual and society as a whole, so many researchers call the human society of the pre-industrial 
era by traditional society. However, even in the modern era, ancient traditions serve as a mobilizing beginning at crucial moments in national history. It is no accident that during the Second World War, the orders of Alexander Nevsky, Suvorov, Kutuzov, Nakhimov, Ushakov and Bogdan Khmelnitsky were introduced in the Soviet Army as military awards, but less than a decade had passed since all these figures were considered reactionaries.

National traditions are usually stable and, even if they are transformed in many ways, they remain consistent even after changes in the socio-economic and political conditions of the people's life. Therefore, tradition is the embodiment of the experience of the nation and the transmission of this experience to the next generations. The interruption of the national tradition threatens the very existence of the people as a nation. In the history of Russia, the fact of the Rurik dynasty suppressing and the election of Godunov, who had no right to the throne, to the Kingdom led to a long-term bloody turmoil that put the Russian state on the brink of destruction. Minor innovations in the service of Patriarch Nikon caused a tragic split in both the Russian self-consciousness, which could only be religious in the 17th century, and society. The 1917 October Revolution would not have been possible without the previous decline of traditional Orthodox-monarchical ideas and views. And, finally, the massive destruction of the Soviet system of values, which was the ideological basis for the unity of all Soviet people united in the USSR that carried out during Gorbachev's Perestroika by 'glasnost' (i.e., publicity), naturally caused the collapse of the entire society.

Although traditions mostly appear as if imperceptibly, gradually consolidating the customs, rituals and elements of national culture that have developed in society, it is still not uncommon to assert the traditions introduced by the authorities, which eventually became completely their own for society. Sometimes historical traditions including holidays, costumes, and certain behaviors are invented artificially, but gradually become 'own' for the people. Moreover, the introduced traditions become the basis for national identity. So, according to the testimony of the English historian H. Trevor-Ruper, such native 'ancient Scottish' symbols as the bagpipe, kilt, cape with clan coloring, and even whiskey, are actually late-introduced. The Scottish bagpipe was invented after 1707, i.e., the year when Scotland lost its independence. Kilt was introduced to the market in 1726-1727 by the English quaker merchant and quaker T. Rawlinson. On an industrial scale, clan cage was put on the fabric by the British brothers Allen. Until the 19th century, the national drink of Scotland was claret and only later truly Scottish declared whiskey. However, all these symbols have become so much a part of the Scottish identity that they are perceived as symbols all over the 
world (Trevor-Roper, 2000). Thanks to these symbols, the Scots, previously divided into Celtic-speaking highlanders and English-speaking lowlanders, as well as representatives of different clans, began to feel like a single community.

Something similar happened to the Basques, who previously did not consider themselves a separate ethnic group but were residents of various historical provinces of Spain and France with a local provincial identity. Starting in 1895, the brothers Arana, who created the Basque nationalist party, began to create separate Basque holidays, national costume and cuisine trying to combine the customs, holidays, costumes and cuisine of different Basque regions into something unified. This has produced results, and now the Basques, of whom only a third speak Basque, are a small ethnic group with a strong national identity.

The desire to create a national tradition under the guise of reviving some old ancient former one was inspired by the idealistic forgers, who published Ossian's poems or, perhaps, forged 'medieval' Czech manuscripts.

The concept of 'tradition' in Roman law meant the transfer of something to heirs. In the Middle Ages, this concept denoted established local customs and features in worship and iconography that did not contradict the canons. In the age of Enlightenment, and later in the philosophy of positivism, tradition became almost an expletive, because it denoted ignorance, superstition and backwardness from this point of view. From the point of view of the enlighteners, tradition is 'remnants of the past' that stand in the way of progress and liberation of the individual. It is no accident that in the pedagogical treatises of that time, for example, Jean-Jacques Rousseau's education meant the upbringing of a 'natural' person, not burdened by any traditions.

Any ideology that aims to create a fundamentally new society that has nothing in common with the existing one automatically considers tradition its enemy. This was typical of the Enlightenment ideology of the 18th century. The Great French Revolution of 1789 was a practical attempt to build a fundamentally different society, based not on traditions but on a predetermined scheme. The best way to eliminate old reactionary views and ideas was the guillotine.

During the Russian Revolution of 1917, the Bolsheviks aimed to destroy all the traditions of the 'cursed past'. The destruction of the traditions of the 'old regime' system of Russia was one of the most important tasks of the Bolshevik party. However, it cannot be said that the Bolsheviks were very successful in this. Although Russian traditions in all spheres of national life were destroyed during the Soviet period but it would be unfair to speak of the complete disappearance of Russian traditions. 


\section{Evolution of philosophical thought about the relevance of folk art}

As a synonym for the concept of 'traditional applied art' is often mixed with folk art.

Things are very difficult with the main definitions in the field of folk art. Many scientists often confuse the concepts of 'folk', 'national', 'decorative', 'traditional'. As a modern researcher Irina Kurakina rightly notes, "the current state of the theory of folk art is characterized by the inaccuracy of the conceptual apparatus, the multiplicity of interpretations of existing concepts. This situation creates inconsistency in their use and unjustified synonymy, an indistinct understanding of the essence and specifics of folk and traditional applied art" (Kurakina, 2018). The classic of the study of Russian folk-art Maria Nekrasova rightly noted that "folk art as a subject of science has not still had a clear definition either in the boundaries or specifics and features that distinguish it from the art of individual creativity of professional artists" (Nekrasova, 1981).

Let's try to understand the basic concepts. We have to start with the main thing: what is the people who create folk art.

The concept of 'people' has many meanings in the Russian language. The entire population of the country can be considered a people (the Constitution of the Russian Federation opens with the words: "we are a multi-ethnic people...") (Constitution of the Russian Federationб 2019). A specific ethnic group (Russian people) is called a people. The word 'folk' meant something inherent in the common people, i.e., standing at the bottom of the social ladder, in many languages, including Russian. In Western European countries, there is still a certain difference between the concepts of 'people' and 'nation'.

Even in the Encyclopedia, published by French thinkers under the direction of Denis Diderot in 1751-1780, there was an article of The People (Peuple), which belonged to the pen of Louis de Jocourt and published in volume 12 in 1765. In particular, it said: "... only workers and farmers remain in the mass of the people" (History in the Diderot and d'Alembert Encyclopediaб 1978). As we can see, skilled artists and artisans were not included in the 'people'. Accordingly, folk art (which was not mentioned in the Encyclopedia...) was something low and primitive. This approach to folk art has still been largely preserved in many countries including Russia.

Jean-Paul Marat, one of the leaders of the Great French Revolution, wrote about the masses: "Poor, rude, ignorant of trade relations, without arts, without crafts but free, they were connected with their land only by reed huts; they lived on the products of their fields, their flocks, their hunting, or voluntarily followed their leaders, the 
spoils of war" (Marat, 1956). Only then the people did develop economically but it lost its freedom and divided into social classes.

In the Russian Empire, the state understood a set of all representatives of the assessor (i.e., unprivileged) classes as 'the people'. Accordingly, folk art refers to the creativity of the social grassroots, usually anonymous creativity based on the aesthetic ideas of the common people remaining outside the attention and understanding of the 'higher spheres' of society, focused on 'world achievements'. Even Vladimir Dabl in his famous Explanatory Dictionary of the Living Great Russian Language noted that 'the people' is the population united by belonging to one state, the inhabitants of the country (Cottage industry, 2006). Dmitry Ushakov wrote about the concept of 'the people' almost in the same terms in his Explanatory Dictionary (Trevor-Roper, 2000).

In this case, we will understand the people as an ethnic group. An ethnic group is defined as an intergenerational blood-related community of people, who have common stable characteristics of language, culture, psyche, self-consciousness, and territory, i.e., an understanding of their differences from other communities and their own unity.

Folk art can be understood as a defined form of folk activity and artistic crafts. The essential features of folk art have always been voluntary (artists were often not professionals, considering their artistic activities as additional income and leisure), initiative, and spiritual motivation. Folk art is considered when the creator of art is the people, and which is based on folk art traditions.

It is especially important to understand the role of tradition in modern folk art. For example, the specific features of Palekh are the principles of ancient Russian painting. According to the well-known researcher of folk-art Maria Nekrasova, "each nation carries its own culture of poetically figurative and craft traditions. Passed down from generation to generation as a result of collective creativity, these traditions acquire stable expressive and emotional structures that pass through the centuries. With tradition in folk art, not only skill is transmitted but also artistic principles, implemented by each time in its own way and bearing its own national character." (Nekrasova, 1981)

Works of traditional art reflect the artistic traditions of the nation, the worldview, worldview and artistic experience of the people, and preserve historical memory. Distinctive features of folk-art crafts are such characteristic features as tradition, collectivity, manual labor, work with natural materials.

However, all of the above is preserved in Russia of the 21 st century, too.

Now let's clarify what 'decorative applied art' is. 
The art and pedagogical dictionary emphasize that "applied art is the art of making household items (utensils, accessories, both for private use, and public, ritual, and religious purposes), which have utilitarian functions at the same time and aesthetic artistic qualities." (Shabanov et al., 2005)

Often experts also use the concept of 'decorative and applied art', which emphasizes the wide use of various decorations in products. The Big Soviet Encyclopedia noted that "works of decorative and applied art are inseparable from the material culture of the modern era, closely related to the corresponding domestic order, with certain local ethnic and national characteristics, social and group ... differences. Making the organic part of the subject environment, which routinely touches people, works of applied art for its aesthetic merits, imagery, character constantly affecting the mental state of a person, his mood, are an important source of emotions, affect their attitude towards the world" (Big Soviet Encyclopedia, 1972).

Therefore, a work of applied art can be perceived as an artistic value and used practically. The complexity of this definition is that artistic quality is also a transformed utility, the result of a spiritual, ideal reinterpretation of the practical needs of man. Therefore, art (in general, as a skillful activity) becomes artistic to the extent that a person manages to transform their practical needs into ideal values.

However, the phrase of 'applied art', due to its ambiguity, should be applied only to those phenomena of creative activity that carry an artistic and figurative content.

The artistic value of applied art is not attached to its material value only. In applied art, one thing passes into another. It is offered to recall that even in the art of the ancient world, the concepts of 'technique' and 'art' were not separated combining them with the general concept of 'techne' in Greek, or 'arsis' in Latin.

In the Middle Ages, there was a special field of artistic crafts, but their functional structure is different from the applied art of Modern Time. Given this fact, experts tend to use different terms: 'art crafts' (German: kunsthandwerk) or 'small art forms' (German: kleinkunst, French: arts mineurs, petit art). There is another German term 'angewandte kunst, which also means applied art although literally this word is derived from 'wandte', from German 'wenden', i.e., 'rotate, change, turn').

After the Renaissance, when there was a final separation of architecture, painting, and sculpture, easel art, i.e., a painting, sculpture, not associated with a specific place in the architectural environment, was formed. Since that time, we can also say that a separate area is occupied by decorative and applied art. In the 19th century, international, national and regional exhibitions of decorative and applied arts 
were held in the world, special museums, for example, the Victoria and Albert Museum in London, or the Museum of Art and Industry in Vienna, were created.

Applied art is divided into types:

- $\quad$ according to the utilitarian function - furniture, utensils, clothing;

- depending on the material used - products made of ceramics, glass, metal, wood, etc.

The specialization of the applied artist depends on the technique of material processing, for example, wood carver, metalworker, porcelain painter. Such masters, according to the classical tradition, combine the skills of an artist (draughtsman, composer, fashion designer) and a craftsman, technologist.

In decorative and applied art, generalization is widely used, even symbolization of the artistic image, which is understood as "a subjective, sensually concrete, integral, individual-special, emotionally expressive form of reflection of reality and self-expression of the artist." (Oganov \& Hangeldieva, 2006) Thus, a significant part of Russian folk art belongs to decorative and applied one. Who produces works of traditional folk decorative and applied art? And what way is they produced?

Any production of material objects including art objects always involves a certain organization of this production. There are three forms of production in applied art throughout its history: craft, handicrafts, and art industry. There is no hard border between these three forms. They all smoothly pass into each other and coexist together.

Artistic craft is small individual manual production, organized on the basis of personal skill with the use of simple tools. Art craft is a method of social and economic organization of craft (Mamontova, 1995). Scientists distinguish three forms of craft: home-made, custom-made, and market-based. However, when it comes to artistic crafts, quite often there is an interweaving of these forms.

A characteristic feature of traditional applied art is its collective character. According to Maria Nekrasova, "each nation carries its own culture of poetic and figurative traditions. Passed down from generation to generation as a result of collective creativity, these traditions acquire stable expressive and emotional structures that pass through the centuries. With tradition in folk art, not only skill is transmitted but also artistic principles, implemented by each time in its own way and bearing its own national character." (Nekrasova, 1982)

As the craft develops, handicrafts take the place of individual craftsmen. Distinctive features of folk-art crafts are such characteristic features as tradition, collectivity, manual labor, work with natural materials. 
Handicrafts (handicraft industry) is the name of small-scale production in Russia. The set of handicrafts was called handicraft industry. Factory industrial production began to mean as 'industry' from the end of the 19th century only. Almost all types of Russian folk arts and crafts have still been related to the cottage industry.

The following features are typical for the cottage industry:

1) mainly domestic industry, i.e., work is done mainly at home and participants in it are usually members of the same family, while wage workers are an exception;

2) as a rule, this activity was a side event;

3) according to the terms of sale of their works, the handicraft industry is closer to large-scale industry (Cottage industry, 2006).

Products were not made to order, i.e., not for a specific customer-consumer (a sign of craft) but were sold wholesale to the market or buyers.

Thus, handicraft industry turns out to be a cross between craft and industrial production. Handicraft differs from handicraft in mass scale: not one master works but a village or even entire counties. That is why the name of crafts always specifically indicates the name of the place where artisans live and work: Palekh miniature, Rostov finift, Vologda lace, Tula samovars, etc. The masters are united in an artel. Home-based nature of production and small-scale production distinguish handicrafts from industrial (factory) production. Handicrafts have always had a stable domestic market and have been successfully exported abroad. Kostroma jewelry from the village of Krasnoe-on-Volga, for example, was sold in India, the furniture made in the old Russian style was in demand in Paris and Brussels, and Tiffany jewelry company in New York sold Siberian stones for 50 years (Levitskiy, 1902). In Soviet times, the concept of 'artisan' became a contemptuous epithet and gradually disappeared, although art artels in the USSR, resembled the old artisan artels, in fact.

Finally, it is logical to say about the art industry although most researchers do not consider it folk art. Art industry is the production of industrial methods of decorative and applied art products that serve for the decoration of everyday life and interior: clothing, clothing and decorative fabrics, machine-made carpets, furniture, art glass, porcelain, earthenware, metal, including jewelry, products, etc. The art industry is an integral part of the industries that produce consumer goods: fabrics, glass, porcelain, metal tableware, etc. However, the products of the art industry differ from other things in the household assortment by the emphasized expressiveness of plastic, ornamental, coloristic, and textured solutions, often being genuine works of decorative and applied art. Works of the art industry are primarily intended to provide aesthetic pleasure to their owners, although they can usually be used 
utilitatively. It should be noted that the legislation of the Russian Federation has not still detected legal definition of the concept of art industry.

The emergence of new materials, for example, previously non-existent types of textiles and new types of dyes, provides unique opportunities in the field of fabric painting. The development of 3D technology leads to a real revolution in the jewelry industry, when a master can use a computer to present a three-dimensional image of the future product. Even in such conservative, truly traditional forms of art that have existed since primitive times, such as ceramics and bone carving, the introduction of new tools provides new opportunities for the development of these types of creativity.

Summarizing the above, it should be noted that:

- folk art, based on traditions, is not limited to copying old, even classical examples of works of art of the past; individual or group artistic creativity will remain in the foreseeable future;

- the development of new technologies can give an impetus to the development of new types or directions of folk art.

Moreover, we can expect a new rise in folk art in modern conditions.

Any country stands on a certain national identity based on religion, language, historical memory, and historical traditions, and, of course, folk art also has its own peculiarities in each country. For example, the lacquer miniature, which was born in China, was developed in Germany, from where it was borrowed by Russia. In all this, the Chinese, German and Russian miniatures are completely different from each other in their subjects, drawing techniques, and colors. It is in art, the art of the people themselves, that the philosophers of the century before last saw the manifestation of the 'Spirit of the People'.

Philosophical thought did not pay attention to folk art for a long time. Going back to the Enlightenment of the 18th century, ideas about 'progress', 'introducing the masses to cultural values' led to the fact that folk art was not just underestimated but considered evidence of 'backwardness'. One of the most important social thinkers of the late 19th century, the founder of social psychology and the theory of 'mass society' Gustave Le Bon (1841-1931) wrote that if France is deprived of fifty of the best entrepreneurs, fifty of the best scientists and fifty of the best writers, artists and actors, it would not be France, but if 150 thousand peasants and artisans disappear overnight, nothing would happen and no one would notice it. 
Sooner or later, European thinkers had to pay attention to the 'low' art of the social grassroots. More precisely, philosophers first paid attention to national identity, which largely determines folk art.

Johann Gottfried Herder (1744-1803) was the first to do this. His main work was the book of Ideas for the Philosophy of Human History. His philosophy was based on the concept of 'people's spirit' ('Volksgeist'). This is the name given to the most characteristic features of a people that find expression in their culture and language. Herder preached the national identity of art, asserted the historical originality and equivalence of various epochs of culture and poetry. "Every nation," wrote Herder, "contains the center of its happiness within itself, just as the globe contains its center of gravity within itself." (Skirbekk \& Guillier, 2003)

But how can we come to a true historical understanding of other unique nations and cultures? According to J.G. Herder, this understanding or assessment cannot be based on general universal standards. He also rejected the notion that one era or nation can serve as the norm or ideal for others. From J.G. Herder's point of view, there is not and cannot be a single progress for all peoples. He predicted a great future for the Slavs as the young peoples of Europe, unburdened by centuries of 'civilization'.

Yet J.G. Herder attributed only folk poetry and music to the folk spirit. He arrogantly ignored folk arts and crafts.

An incomparably more important contribution to the philosophical understanding of traditional folk art was made by Johann Gottlieb Fichte (1762-1814). He was one of the most prominent philosophers, notable even for the era when German classical philosophy was developing and rising. The defeat and occupation of the German states by Napoleon in 1806 dramatically changed Fichte both as a person and philosopher. From that moment, the German nation and its 'people's spirit' became the basis of J.G. Fichte's creativity. He wrote about the potential future of the all-German state: "in order for the emerging state not to return to the Asian despotism, but to accept the universal equality of law already developed among the Greeks and Romans, it was necessary that its main elements should be imbued with a common European national character, a lively sense of right and freedom and love for them, and with these features combine a still subtle sense of honor." (Fichte, 1906)

At the beginning of the 19th century, under the influence of disillusionment with the Enlightenment philosophy and its belief in boundless progress, which ended with the French revolution and the Napoleonic wars, romanticism as a special trend 
in art that contrasted itself with Enlightenment in philosophy and classicism in art, emerged.

In contrast to the enlighteners with their calls for progress to discard all the old, the romantics gave great influence to national folklore and traditional crafts. Representatives of the romantic school emphasized the primordial nature of folk art contrasting it as something natural, refined professional art. This was especially distinguished by the circle formed in the city of Heidelberg, whose members turned to antiquity and folklore, in 1805-1809. For example, two of the members of the circle, the brothers Wilhelm and Jacob Grimm, carefully studied the peculiarities of the language and folklore of the German people.

The emphasis on language learning was not accidental. The great scientist of the time, the founder of the University of Berlin, and the outstanding philologist, Wilhelm Humboldt noted that "language is the spirit of the people, and the spirit of the people is its language." $W$. Humboldt's thesis about language as the spirit of the people should be understood in such a way that language finds its embodiment in the way of thinking of the people, and the way of thinking of the people is embodied in its language. Therefore, the language is an external manifestation of the 'spirit of the people', since it reflects its national character, the complex of intellectual values, the totality of the culture of the people, and its spiritual education.

However, romantics looked at folk art only as a source of inspiration and manifestation of the 'folk spirit'. Folk art began to be explored somewhat later, in the middle and second half of the 19th century. Since then, ethnography, cultural studies, and some sections of art history have collected, classified, and analyzed features of the artistic style, trends, and variants of folk art. However, all these sciences study, if I may say so, folk traditional art in statics, as of such a year. With all due respect to ethnographers, the prospects for the development of folk art remain outside their scientific sphere.

Gottfried Semper (1803-1879) spoke for the first time about the fact that the industrial era can give rise to a new folk art. In 1851, the world's exhibition was held in London. That was the first of the world's art and industrial exhibitions in history. It has laid down the methodology for the conduct of such exhibitions and had a huge impact on many types and directions in art. The exhibition was visited by 6 million people - quantity previously unseen in history. G. Semper was among the visitors. Soon after the exhibition, he published the book of Science, Industry and Art, where he gave a comprehensive artistic analysis of all contemporary culture through the analysis of those works of art that were presented there. In it, he tried to analyze modern culture from the point of view of the relationship between mass industrial 
production and artistic creativity. Semper considered the style as a historical phenomenon. He saw the reasons for the decline of architecture and crafts of the 19th century in the separation of technology and art, and separation of decoration from construction. Linking the laws of form formation with the functions of art works, G. Semper understood the artistic principle as a symbolic 'garment' of construction and materials. It was Semper, who introduced the concept of 'artistic craft' ('das Kunstgewerbe'), which reflects the artist's intervention in the production of material things in order to achieve a lost correspondence between the aesthetic and purely physical qualities of the forms of the object world.

In England, a prominent art theorist who turned to traditional folk art was John Ruskin (1819-1900). He was critical of the mass factory production that was killing traditional crafts. In his opinion, factory production led to the degradation of both the creator and the buyer of the product. J. Ruskin called on artisans to overcome the dehumanizing effects of mechanized labor with the help of art and industrial workshops. He even headed a craft workshop, which created remarkable examples of decorative and applied art.

J. Ruskin's friend and follower, William Morris (1834-1896), a poet and artist who is considered the forerunner of design, created the Arts \& Crafts Movement, whose members were engaged in the manual production of decorative and applied arts, seeking to bring art and craft closer together. The aim of the movement was to promote traditional craft production. Furniture and interior design, new approaches in a number of other applied arts - all these developments of Morris and his movements had an impact on many areas of art of the 20th century.

Thus, contrary to the simplistic vision of the Enlightenment philosophy, which believed that the inexorable pace of technological progress would sweep away the 'backward' forms of artistic life, traditional art was very able to exist and thrive in the conditions of industrial production even in Europe.

In Russia, the classics of Slavophilism of the 19th century philosophically justified the civilizational identity of Russia. This is their enduring significance before Russian culture. Slavophiles have the world priority in philosophy that during the triumph of progressive theories, they were the first to express the idea (not obvious at that time) that there is no single world civilization, the symbol of which is the 'advanced' countries of Western Europe, and other 'underdeveloped' countries should run after the West importing Western civilization with all its roses and thorns. Slavophiles pointed to the independence of individual local civilizations.

From their point of view, it is culture that gives the most characteristic features of each civilization. Under the influence of Slavophiles, researchers traveled on foot 
to dozens of provinces recording folk songs and epics, and collecting collections of handicrafts.

Not only studying and collecting, but also a successful attempt to create a new national art was carried out by an informal association of Russian creative intelligentsia (artists, musicians, theater workers, scientists), who formed the so-called Abramtsevo Circle (Mamontov Circle). This circle operated in the 1870s-90s in Abramtsevo, the estate of the entrepreneur and philanthropist Savva Mamontov. In Abramtsevo, the revival of lost and forgotten Russian folk crafts began: wood carving, tiles, embroidery. Artists organized expeditions to northern Russian cities to study preserved ancient monuments of architecture, iconography, decorative and applied arts, and searched for examples of folk art in villages. Members of the circle organized carpentry and carving, embroidery and pottery workshops in Abramtsevo. The products of the workshops were very popular, exhibited at all-Russian and international exhibitions, and won gold medals. The rise of new Russian art, based entirely on folk art traditions, was hit by the political problems of the first third of the 20th century.

In the Soviet period of Russian history, despite the fact that the Bolsheviks fully shared the progressive ideas that came from the philosophy of the Enlightenment, and artists, who worked in the traditional manner, were viewed as a 'backward element', folk art crafts did not disappear. Moreover, in the 1920s and 30s, new centers of lacquer miniatures appeared in Palekh, Mstera and Kholui. Unemployed iconographers found their place in art there.

In the Soviet era, traditional Russian art was studied and popularized by a number of remarkable scientists. Among themo we can name Nikolai Dmitrievich Bartram, Anatoly V asilyevich Bakushinsky, Viktor Mikhailovich V asilenko, Vasily Sergeyevich Voronov, and other remarkable scientists.

The achievements of the country's traditional art in the first decades of the Soviet era were clearly demonstrated by the international exhibition of art and technology held from May 25 to November 25, 1937 in Paris, which became a triumph of Soviet science, technology and art. The Soviet exposition at the exhibition collected 270 awards including 95 Grand Prix, 70 gold, 40 silver, 6 bronze medals, more than fifty diplomas. The triumph was particularly impressive, given the open hostility and bias of the jury, and the noisy anti-Soviet campaign in the press.

After the Second World War, Russian traditional art found itself in a paradoxical position: it became an officially recognized historical value of the country, but recognition did not mean that this art would continue to develop and not remain the storage units of museums. In 1960, almost all art artels, which turned into ordinary 
factories, were liquidated. In these conditions, we can wonder only that Russian traditional art has survived at all.

In addition to political problems, there were also social and cultural problems common to all industrialized countries. In the course of a single generation, Russia has transformed from a predominantly peasant country to a country of citizens. In 1897, the urban population of Russia was $12.9 \%$ of the total population, $15.3 \%$ in $1914,21.3 \%$ in 1926 , and already $74.4 \%$ in 1979 . The traditional peasantry has completely disappeared as a class. The artisanal sector of the economy has also almost disappeared, or rather, it has become 'shadow'. As a result, traditional art has largely disappeared, and what existed was mostly presented as kitsch products for tourists.

Of course, folk art could only be preserved and developed as a result of the existence and active activity of educational institutions that train personnel for folk crafts. Such figures as V.M. Vasilenko, N.G. Dmitriev, M.A. Nekrasova and others, who created scientific research on professional education in the field of folk arts and crafts, played a huge role in this.

The Moscow School of Arts and Crafts (MSAC), founded in 1938, trained specialists in traditional applied arts during the Soviet era. It was there that the world's first author's training programs were created for professional skills in the field of embroidery, art painting on metal, fabric, and jewelry. A specific quality of the School's staff was a highly professional attitude to folk art not as a frozen phenomenon but as a living phenomenon that is still in demand today (Folk art: history and modernity, 2006).

Traditional applied art was in this position in Russia by the end of the Soviet era. The collapse of the Soviet Union contributed to a sharp acceleration of the world process called globalization.

The most characteristic feature for all countries of the world is the identity crisis in the era of globalization. This term 'identity' (Lat. idem - 'the same') appeared in ancient logic and meant a relation, whose members are identical to each other. However, of course, identity is not just a philosophical category. Identity in the human psyche is the ability to express in a concentrated form for a person how a person imagines personal belonging to various social, national, professional, linguistic, political, religious, racial and other groups or other communities. In other words, what the individual relates to is identity. First of all, an individual's identity is related to his or her cultural preferences. People can change their spouse, religion, political views, country of residence, social status, even sexual orientation many times. However, culture defines all other identities. 
In the age of globalization and the 'blurring' of identity by western 'mass culture', the importance of the cultural factor for the preservation of identity is only increasing. In fact, only those nations that have their own cultural alternative, will survive in the modern world.

The era of globalization with its imposed patterns of western mass culture, highly likely, caused an identity crisis. And the counteraction to globalization was the 'return of ethnicity', i.e., the revival of almost forgotten historical cultural traditions. We must admit that in a number of historical provinces of European countries, there is a real revival of traditional applied art. In Russia, this process has also taken on a special character. It is no coincidence that philosophers talk about the conservative cultural revolution in Russia. And it is in the field of traditional arts (since 'modern' arts are formed in the West) where the victory in preserving the Russian national identity can be won.

\section{The current situation with the training of specialists in the field of folk art in Russia}

However, this requires a system of training future artists. At the turn of the Millennium, Russian traditional applied arts began to require new approaches to teaching. It was necessary to train not only diligent copyists of old classical examples of traditional applied art but also artists, who could develop the Russian artistic tradition in the era of universal literacy, urbanization and mass media domination. However, artists need higher education in order for national art would not limit only to the restoration of old techniques and products. For thousands and thousands of years, traditional art has been based on the practical experience of masters based on the examples of their ancestors. However, this is not enough in our time. A modern artist, who wants to create great masterpieces, which is the natural feeling of every true artist, must have all the artistic experience of humanity and especially his people but also be a comprehensive person. Meanwhile, in the 'wild 1990s', the traditional arts and crafts of Russia experienced a severe crisis. In addition to prosaic financial problems, people's artists were particularly affected by the beginning dominance of mass western culture. However, as always in the history of Russia, all these problems caused natural resistance. On the wave of increased interest in the basics of national culture in Russia, the opening of the Higher School of Folk Arts (Institute) took place in 2003. The HSFA(I) is really the first and only state educational institution in Russia that provides professional training for artists of traditional applied art.

A unique system of continuing professional education in the field of traditional decorative and applied arts is embodied in it. The Institute is a multi-level educational 
institution of higher professional education that implements programs of secondary, higher, and additional professional education. Thus, the HSFA(I) is not only an educational but also a scientific institution, the only one of its kind.

HSFA(I) branches are located throughout Russia and abroad: Moscow, Mstera, Kholui, Bogorodsk, Fedoskino, Sergiev Posad, Omsk, Ryazan, Porvoo (Finland). The number of students at it is small. However, it is quite understandable: an artist of traditional art is a piece product.

Thus, the HSFA(I) is both a higher education institution and a research center where Russian traditional folk art continues to develop. There are many difficulties and contradictions in the development of the Institute, as well as in the state of traditional applied art. However, Georg Wilhelm Friedrich Hegel also noted that contradiction is the source of development.

\section{Conclusion}

Thus, Russian traditional applied art having survived all the troubles and misfortunes, continues to exist. At the same time, traditional art directly affects the 'high' art of the nation. As historical experience shows, for example, in the work of $W$. Morris and the work of the Abramtsevo Circle, traditional art has an inspiring effect on the art of the country as a whole. In other words, not only elements of folklore but also new, quite avant-garde art still comes from a folk source.

We can observe the emergence of new types of folk art with our own eyes.

As an example of the development of 'real' folk art in the middle and end of the Soviet era, we can cite the history of the appearance of artistic processing of amber. This direction was born in the Kaliningrad region, former East Prussia, after 1945. In the Russian Federation, this region is the smallest of territory - 15.8 thousand square kilometers ( $0.3 \%$ of the country's territory) (Lebedev, 2015). The region is inhabited by immigrants from all over the former USSR. As the Kaliningrad scientist Y. Zverev noted, "in the economic and geographical literature there is a term 'countries of migrant capitalism'. In this sense, the region can be called a 'region of migrant socialism' with all its inherent pros and cons." (Zverev, 1997) There are many universities in the region including the university. Kaliningrad residents are mostly citizens with a high level of education. However, it is here that the artistic processing of amber has become completely 'its own', Russian direction in art. Thus, the artistic processing of amber is completely related to Russian folk applied art. Amber jewelry has become one of the 'business cards' of Russian jewelry art. The Kaliningrad amber industry has lived more than 50 years.

Can we talk about the possibility of new types of folk art? 
Let's give an example of such popular among 'ordinary people', types of home art that have a long history and have flourished in our time, as patchwork sewing and making glass products with a burner at home.

Patchwork is a type of folk-art activity that has existed from time immemorial to the present day. Traditions of patchwork sewing were developed in Russia. So, Domostroy described methods of economical cutting, including from scraps of cloth. In the Soviet era, patchwork was also interested in artists, futurists, and constructivists of that time as a new expressive form. Most people, however, were engaged in making clothes from rags only because of poverty and scarcity. Patchwork is a kind of mosaic made of pieces of fabric, which is used to create household items, clothing, accessories, and art panels. This art can be both decorative and applied, and purely artistic. If earlier patchwork arose from the need to maximize the use of all available fabrics, today patchwork is becoming a real art, and millions of people, women and men, young and old, of all social strata and groups are interested in it.

Lampwork (working with a burner) is a technique for processing glass over the flame of a burner. It is one of the newest types of folk art. It is usually used for making glass beads, accessories, and small decorative figures. For lampwork, you need special equipment: a propane or oxygen burner, as well as quite expensive raw materials. Historically, since ancient times, glassblowers made toys and trinkets from the remains of the glass mass. At the end of the 20th century, as burners and glass for processing became available and cheap, lampwork began to turn into an art craft. The main advantage is the ability to let in products of any shape and size. In addition, all lampwork products are unique because it is impossible to repeat them.

Of course, these examples are not limited to folk art. We can expect the emergence of new directions in this work, caused by the development of technology. Consequently, folk art will exist and develop in new forms that are not yet known to us.

\section{References:}

Big Soviet Encyclopedia. (1972). In 30 vols. 3rd ed. Vol. 8. Moscow: Soviet Encyclopedia.

Constitution of the Russian Federation. (2019, April 11). Retrieved June 15, 2021, from http://www.constitution.ru/

Cottage industry. (2006). Holy Russia. Great Encyclopedia of the Russian People. Moscow: Russian Economy. 
Dal, V.I. (1995). Explanatory dictionary. In 4 vols. Vol. 2. Moscow: Terra Edition Center.

Fichte, I.G. (1906). The main features of the modern era. St Petersburg.

Folk art: history and modernity. (2006). Interview with the rector V.F. Maksimovich.

Autumn school of traditional applied arts. November 15, 2006. Program and training materials. St Petersburg.

History in the Diderot and d'Alembert Encyclopedia. (1978). Leningrad: Nauka.

Kurakina, I.I. (2018). Content of teaching the theory and history of traditional applied art in specialized higher education. St Petersburg: VSHNI.

Lebedev, S.V. (2015, January 16). Yantarnaya Rus. Ethnic history of the Kaliningrad region. Russian People's Line. Retrieved March 22, 2021, from https://ruskline.ru/analitika/2015/01/16/rus yantarnaya

Levitskiy, V. (1902). Importance of Handicrafts in the national economy / / National Economy, Vol. 2.

Mamontova, N.N. (1995). Features of development of folk crafts and crafts of Russia from the 18th to early 20th century. Folk art of Russia: Tradition and Style, 86. Moscow: Proceedings of GiMA.

Marat, J-P. (1956). Selected works. Vol. 1. Moscow.

Nekrasova, M.A. (1981). Folk art creativity as a type of artistic creativity. Art, 11. Moscow.

Nekrasova, M.A. (1982). Problems of folk art. Moscow: Fine Art.

Oganov, A.A., Hangeldieva, I.G. (2006). Theory of art: Textbook for independent work of students. Moscow: Publishing House of the International University in Moscow.

Shabanov, N.K., Shabanova, O.P., Tarasova, M.S., Pronina, T.D. (Comp.) (2005). Art and pedagogical dictionary. Moscow: Akademicheskiy Prospekt: Triksta.

Skirbekk, G., Guillier, N. (2003). History of philosophy. Moscow: Humanitarian Publishing Center VLADOS.

Trevor-Roper, H. (2000). The Invention of Tradition: The Highland Tradition of Scotland. The Invention of Tradition. Cambridge: Cambridge University Press.

Ushakov, D.N. (1996). Explanatory dictionary. Vol. 2. Moscow: Terra Edition Center. Zverev, Y. (1997). Kaliningrad region of Russia in a new system of geopolitical coordinates. Ethnic and Regional Conflicts in Eurasia, 2. Moscow: Whole World. 